\title{
Using an industry survey to obtain faculty support for ABET 2000 criteria
}

\author{
Peter A. Koen \\ ASEE/Stevens Institute of Technology
}

\begin{abstract}
Change is often very difficult. Survey's which examine market and competitive realities are often rejected when they are not developed by the people who need to implement the change. This paper describes a four step process for developing and implementing an industry based survey using a powerful coalition of faculty. Initial findings of the survey indicate that the most important ABET criteria are the "softer skills" which are: the ability to identify, design and conduct experiments as well as analyze results; formulate and solve engineering problems; to engage in life-long learning; function on a multi-disciplinary team and communicate effectively. This survey indicates that engineering schools will need to improve on the "softer skills" while maintaining their strength in teaching the "harder" technical skills. As engineering schools embrace the assessment requirements of ABET 2000 they need to develop a survey process where the results will be embraced by the faculty and implemented into curriculum change. The key issue is not the survey, but the process utilized.
\end{abstract}

\section{Introduction}

Engineering schools are becoming more responsive to the needs of the undergraduates future employers. Employers are no longer accepting a passive role in the education process and are exerting their influence by decreasing the number of schools at which they recruit and financially support. This change is further being accelerated by the inclusion of outcomes and assessment measurements as a consequence of the expected adoption of the ABET Engineering Criteria $2000^{1}$. Which outcomes and assessments indicated in the ABET should be emphasized? Will the faculty, who are the owners of the curriculum, agree with the prioritization and make appropriate changes so that the curriculum is aligned with the outcome expectations?

A pilot study ${ }^{2}$ was conducted in 1996 to assess the expectations and preparedness of Stevens Institute of Technology top 20 employers. Preliminary results verified many of the attributes indicated in the ABET Engineering Criteria. Our expectation was to expand this survey to include additional employers. However the results were rejected by many faculty at the Institute for multiple reasons. Some of the reasons given were: that the survey was not asking the right questions; that the questions were not worded correctly; and that it had not sampled the correct people. These criticisms, for the most part, were valid and could have been ameliorated by modifying the survey. However, the major issue, which was not properly addressed in designing 
the survey for the pilot study, was understanding the change and upheaval which the survey results would promulgate on the faculty.

A survey which assess the preparedness of undergraduates to meet the needs of their employers may strongly indicate that courses, curriculum and faculty who teach them need to change. Surveys of this nature are destined to fail, no matter how well designed, if they are not developed in concert with the faculty who need to change. Change efforts often fail if a powerful coalition ${ }^{3}$ of faculty who support the survey are not included in the design of the instrument. The assessment instrument designed by Arizona State University ${ }^{4}$ was developed by a 20 member Task Force that presumably meet this requirement. The survey instrument developed by Auburn University ${ }^{5}$ was done by a "Quality Standards Committee" whose make-up was not discussed.

This paper reviews the 4 step process used to develop a new survey, which has been accepted by the faculty at the Institute. In addition the implementation process as well as the results are discussed and compared to previous studies ${ }^{2,4,5}$ as well as to the ABET criteria ${ }^{1}$.

\section{Survey Design Process}

The new survey instrument was developed by a faculty team consisting of 13 senior faculty representing each of the engineering and science departments at the Institute. The team was carefully chosen so that they would represent a powerful coalition. The survey was developed in four major steps. The $1^{\text {st }}$ step was to formalize the faculty team with the process and previous studies $^{2,4-8}$. The $2^{\text {nd }}$ step was to have the faculty team develop the survey. Each faculty in their respective discipline was charged with developing a series of questions concerning current and future behavior, work habits, basic, core and technical skills required of undergraduates. (Initially, skills specific to each of the engineering disciplines were included in the survey, but were later excluded due to the small sample anticipated from the specific discipline.) The survey questions were then assembled and reviewed many times with the faculty so that a consensus instrument, including questions and format, was developed.

In the $3^{\text {rd }}$ step the survey instrument was reviewed in a meeting with industry representatives who represented the Institute's top employers. The purpose of this meeting was two fold. The $1^{\text {st }}$ was to obtain consensus by the faculty on the importance of the survey and the merit of the questions. Some faculty members remained recalcitrant on the inclusion of certain questions. The focus group was utilized as a mechanism to achieve consensus. The $2^{\text {nd }}$ reason was to determine if the employers identified any survey areas which were omitted.

During this meeting the employers indicated that the survey should only be mailed to alumni who have graduated from the Institute over the last 3 years. They indicated that students attributes become significantly influenced by company learning after this period. None of the previous studies $^{2,4-8}$ limited their alumni cohort to the last 3 years. The final $4^{\text {th }}$ step was to implement a pilot test of the survey to insure that the instructions and questions were worded correctly. This was done by mailing the survey to 10 alumni, all from different companies, and conducting phone interviews with them following their response to the instrument. 


\begin{tabular}{|c|c|}
\hline ABET 2000 Criteria & Stevens Undergraduate Survey \\
\hline $\begin{array}{l}\text { 1. Ability to apply knowledge } \\
\text { of mathematics, science and } \\
\text { engineering. }\end{array}$ & $\begin{array}{l}\text { 1. Fundamental understanding of mathematics. } \\
\text { 2. Fundamental understanding of Physical and Life Sciences. } \\
\text { 3. Breath of engineering sciences (Ability to understand the basic concepts in } \\
\text { most of the } 7 \text { engineering sciences: Mechanics of Solids; Fluid Mechanics; } \\
\text { Thermodynamics; Heat, Mass \& Momentum Transfer; Electrical Theory; } \\
\text { Nature \& Properties of Materials and Information Theory). }\end{array}$ \\
\hline $\begin{array}{l}\text { 2. Ability to design and } \\
\text { conduct experiments, as well } \\
\text { as to analyze and interpret } \\
\text { data. }\end{array}$ & $\begin{array}{l}\text { 4. Ability to use computers for communication, analysis and design. } \\
\text { 5. Effective decision making (prioritizing goals, generating alternatives and } \\
\text { choosing the best alternative). } \\
\text { 6. Effective problem solving. }\end{array}$ \\
\hline $\begin{array}{l}\text { 3. Ability to design a system, } \\
\text { component or process to meet } \\
\text { desired needs. }\end{array}$ & $\begin{array}{l}\text { 7. Effective project management skills. } \\
\text { 8. Depth of engineering sciences (Ability to understand the basic concepts in } \\
\text { most of the } 7 \text { engineering sciences). } \\
\text { Ability to use computers for communication, analysis and design (repeat as } \\
\text { item 4). }\end{array}$ \\
\hline $\begin{array}{l}\text { 4. Ability to function on multi- } \\
\text { disciplinary teams. }\end{array}$ & 9. Effective team skills. \\
\hline $\begin{array}{l}\text { 5. Ability to identify, } \\
\text { formulate and solve } \\
\text { engineering problems. }\end{array}$ & $\begin{array}{l}\text { 10. Ability to develop innovative approaches. } \\
\text { 11. Exert high levels of effort, strives to achieve goals } \\
\text { Effective problem solving. (repeat as item 6). }\end{array}$ \\
\hline $\begin{array}{l}\text { 6. An understanding of } \\
\text { professional and ethical } \\
\text { responsibility. }\end{array}$ & $\begin{array}{l}\text { 12. High professional and ethical standards. } \\
\text { 13. Mature, responsible and open minded with a positive attitude towards life. }\end{array}$ \\
\hline $\begin{array}{l}\text { 7. Ability to communicate } \\
\text { effectively }\end{array}$ & $\begin{array}{l}\text { 14. Effective listening skills. } \\
\text { 15. Effective oral communication. } \\
\text { 16. Effective writing skills. }\end{array}$ \\
\hline $\begin{array}{l}\text { 8. Broad education necessary } \\
\text { to understand the impact of } \\
\text { engineering solutions in a } \\
\text { global and societal context. }\end{array}$ & $\begin{array}{l}\text { 17. Appreciation and understanding of history, world affairs and cultures. } \\
\text { 18. Able to function in a multicultural and diverse work environment. } \\
\text { Breath of engineering sciences (repeat of item 3). }\end{array}$ \\
\hline $\begin{array}{l}\text { 9. Recognition of the need for } \\
\text { an ability to engage in life- } \\
\text { long learning. }\end{array}$ & 19. Motivation and capability to acquire and apply new technologies. \\
\hline $\begin{array}{l}\text { 10. Knowledge of } \\
\text { contemporary issues. }\end{array}$ & $\begin{array}{l}\text { Appreciation and understanding of history, world affairs and cultures (repeat } \\
\text { of item 17). }\end{array}$ \\
\hline $\begin{array}{l}\text { 11. Ability to use the } \\
\text { techniques, skills and modern } \\
\text { engineering tools necessary for } \\
\text { engineering practice }\end{array}$ & $\begin{array}{l}\text { 20. Fundamental understanding of cost estimation and accounting. } \\
21 \text {. Fundamental understanding of engineering economic analysis and decision } \\
\text { making. } \\
\text { 22. Knowledge of business strategies and management practices. } \\
\text { 23. Effective in dealing with real world complex and ambiguous problems. } \\
\text { 24. Able to transition from academic environment to the industrial } \\
\text { environment. } \\
\text { Effective project management skills (repeat of item } 7 \text { ). } \\
\text { Able to function in a multicultural and diverse work environment(repeat of } \\
\text { item 18). }\end{array}$ \\
\hline
\end{tabular}

Table 1. Attributes of the Institute's undergraduate survey compared to the ABET 2000 Engineering Criteria. 
A total of 24 attributes were included in the survey and are shown in Table 1. These attributes are compared to the ABET Engineering criteria $2000^{1}$ program outcomes and assessments. The Institute's survey covers 9 of the 10 survey questions included in the University of Arizona study". "A motivation and capability to continue the learning experience" is included in the University of Arizona ${ }^{4}$ study, but is not contained in the Institute's survey. A similar comparison with the Auburn ${ }^{5}$ study shows similarities in 8 of the 16 attributes. Presumably, it would be valuable to standardize the survey instrument in order to compare responses between schools. However, standardization should not jeopardize faculty acceptance of the survey tool since the major purpose of the survey instrument is to help implement change. Different schools will and should have different objectives and thus should be prepared to measure them using a customized survey instrument developed by the faculty of their own school.

\section{Survey Implementation}

The survey was mailed to all 645 undergraduates who graduated from the Institute during the last 3 years (i.e. 1994, 1995 and 1996). The mailings were conducted in 3 rounds with 2 free domestic airline tickets given away by lottery to one of the respondents who filled out the survey in order to increase the return percentages. To maintain confidentiality the survey was mailed in two parts. The $1^{\text {st }}$ part, which was returned separately, identified the student so that we could keep track of the respondents. The $2^{\text {nd }}$ part was the actual survey. The author believes that confidentiality of the response is essential since part of the survey addressed how well the students believed that the Institute prepared them.

Each of the alumni were asked to evaluate the importance of the skill to their company on a 5 point scale. Choosing a 5 would indicate that the skill is "extremely important" and a 1 if it is "not important". The alumni were also asked to rate how well the Institute prepared them, as well as how well they thought employees from other schools, in their company, were prepared. The importance of the skills to the alumni are discussed in this paper. Institute preparedness will be discussed in a subsequent paper.

\section{Survey Results}

The results are shown in Table 2 which consisted of a response rate of $20 \%$. The attributes are shown in order of priority determined from the "top-box rating" or the percentage of alumni who rated the attribute importance level as being "extremely important" to their company. The top five were effective problem solving, use of computers for communication, analysis and design, effective decision making, effective oral communication and exert high levels of effort. At the bottom of the list were breath (attribute number 20) and depth of engineering science (attribute number 23).

These results are also shown in Table 3 by "top-box rating," but in terms of the ABET Criteria. Table 3 was determined by averaging the \% "top box rating" indicated in Table 2 according to the categories designated in Table 1. The groupings in Table 3 provide similar results indicating that the ability to identify, design and conduct experiments as well as analyze results; formulate 
and solve engineering problems; to engage in life-long learning; function on a multi-disciplinary team and communicate remain key attributes required of graduating engineers.

\begin{tabular}{|c|c|}
\hline Attribute & Alumni (\%) \\
\hline 1. Effective problem solving. & 75 \\
\hline 2. Use of computers for communication, analysis and design. & 70 \\
\hline 3. Effective decision making. & 68 \\
\hline 4. Effective oral communication & 65 \\
\hline 5. Exert high levels of effort, strives to achieve goals & 64 \\
\hline 6. Motivation and capability to acquire and apply new technologies. & 63 \\
\hline 7. Effective listening skills. & 63 \\
\hline 8. Effective team skills. & 62 \\
\hline 9. High professional and ethical standards. & 60 \\
\hline 10. Ability to develop innovative approaches. & 54 \\
\hline 11. Effective in dealing with real world complex and ambiguous problems. & 53 \\
\hline $\begin{array}{l}\text { 12. Ability to transition from the academic environment to the industrial } \\
\text { environment. }\end{array}$ & 50 \\
\hline 13. Effective project management skills. & 50 \\
\hline 14. Mature, responsible and open minded with a positive attitude towards life. & 50 \\
\hline 15. Effective writing skills. & 49 \\
\hline 16. Ability to function in a multicultural and diverse work environment. & 47 \\
\hline 17. Knowledge of business strategies and management practices. & 35 \\
\hline 18. Fundamental understanding of mathematics. & 32 \\
\hline 19. Appreciation and understanding of history, world affairs and cultures. & 27 \\
\hline 20. Breath of engineering science. & 26 \\
\hline $\begin{array}{l}\text { 21. Fundamental understanding of engineering economic analysis and decision } \\
\text { making. }\end{array}$ & 24 \\
\hline 22. Fundamental understanding of physical and life sciences. & 18 \\
\hline 23. Depth of engineering sciences. & 14 \\
\hline 24. Understanding of cost estimation and accounting. & 8 \\
\hline
\end{tabular}

\section{Table 2. Survey results in order of priority. The second column is the percentage of alumni who rated the attribute as being "extremely important."}

The relative importance of these results are comparable to the study done at University of Arizona ${ }^{4}$ with problem solving and communication skills receiving the highest priorities by their alumni. These same areas are comparable to the $2^{\text {nd }}$ and $5^{\text {th }}$ priorities in Table 3.

\section{Discussion}

This study is significantly improved over the pilot study ${ }^{2}$ with the number of attributes expanded from the original 13 to 24 . More importantly, it was designed by a coalition of faculty who could affect change and help promulgate the findings. The results of the survey are still being debated at the Institute. However, there is considerably less criticism directed at the survey. Criticism is now directed at the new curriculum which is being designed to provide the students with a broader experience with more emphasis on the "softer skills". 


\begin{tabular}{|l|c|}
\hline \multicolumn{1}{|c|}{ ABET 2000 Criteria } & $\begin{array}{c}\text { Alumni } \\
\text { (\%) }\end{array}$ \\
\hline $\begin{array}{l}\text { 1. Ability to design and conduct experiments, as well as to analyze and } \\
\text { interpret data. }\end{array}$ & 71 \\
\hline 2. Ability to identify, formulate and solve engineering problems. & 64 \\
\hline 3. Recognition of the need for an ability to engage in life-long learning. & 63 \\
\hline 4. Ability to function on multi-disciplinary teams. & 62 \\
\hline 5. Ability to communicate effectively & 59 \\
\hline 6. An understanding of professional and ethical responsibility. & 55 \\
\hline 7. Ability to design a system, component or process to meet desired needs. & 45 \\
\hline $\begin{array}{l}\text { 8. Ability to use the techniques, skills and modern engineering tools } \\
\text { necessary for engineering practice }\end{array}$ & 41 \\
\hline $\begin{array}{l}\text { 9. Broad education necessary to understand the impact of engineering } \\
\text { solutions in a global and societal context. }\end{array}$ & 33 \\
\hline 10. Knowledge of contemporary issues. & 27 \\
\hline 11. Ability to apply knowledge of mathematics, science and engineering. & 25 \\
\hline
\end{tabular}

\section{Table 3. Survey results, in order of priority, and structured in terms of ABET 2000 criteria. The second column is the percentage of alumni who rated the attribute as being "extremely important."}

This study assigns relative priorities to the ABET criteria indicating that the most important attributes are the ability to identify, design and conduct experiments as well as analyze results; formulate and solve engineering problems; to engage in life-long learning; function on a multidisciplinary team and communicate effectively. Less important are breath and depth of the technical skills. These are important findings which should guide the direction of curriculum changes which need to emphasize "softer skills." The challenge is for the new curriculum to maintain the engineering skill level while supplementing it with "softer skills". These results help lead us into the new millennium where graduating engineers will need to have both superior technical and soft skills. Engineering schools have consistently provided graduates with technical skills, but provided little, if any, education into the softer skills. Surveys like this one emphasize the importance of the softer skills and help provide the sense of urgency ${ }^{1}$ which is needed to guide change.

The value of this work lies in the process utilized to create and implement a survey. Assessment of alumni and their employers by surveying their needs and the graduates preparedness is a tool that will be more utilized by many schools as the new ABET criteria is embraced. The survey is only valuable if it produces change. Developing a new curriculum, which often results in faculty displacement since new courses must be developed and old courses eliminated or restructured, should be the end result of the survey process. The survey results are destined to be rejected if they don't involve the faculty who need to make the change since it is easier to criticize the survey rather than to change.

In order to accomplish this a powerful faculty coalition who can help guide course and curriculum change should be involved in developing the survey with the students most important employers. The questions developed are less important than the survey process. 


\section{Bibliography}

1. Engineering Criteria 2000, December 1997, $3^{\text {rd }}$ edition, Accreditation Board for Engineering and Technology, Maryland.

2. Koen, P.A., "Undergraduate Engineering Skill Preparedness," Proceedings, 1996 ASEE Annual Conference, CD ROM Reference \#2242.

3. Kotter, J.P., "Leading Change: Why Transformation Efforts Fail," Harvard Business Review, pg. 59-67, MarchApril 1995.

4. Evans, D.L., Beakley, G.C., Crouch, P.E., and Yamaguchi, G.T., "Attributes of Engineering Graduates and Their Impact on Curriculum Design,” Journal of Engineering Education, pg. 203-211, October 1993.

5. Benefield, L.D., Trentham, L.L., Khodadadi, K., and Walker, W.F., "Quality Improvement in a College Engineering Instructional Program,” Journal of Engineering Education, pg. 57-68, January 1997.

6. Hoyt, D.P., and Muchinsky, P.M., "Occupational Success and College Experiences of Engineering Graduates," Engineering Education, pg. 622-623, May 1973.

7. Muchinsky, P.M., "Performance Ratings of Engineers: Do Graduates Fit the Bill?," Engineering Education, pg. 187-188, November 1974.

8. Van Horn, C.E., "Enhancing the Connection Between Higher Education and the Workplace: A Survey of Employers," State Higher Education Executive Offices (SHEEO), Denver, CO., 1995.

\section{Biographical Information}

Dr. PETER A. KOEN is a full time Associate Professor in the Wesley J. Howe School of Technology Management at Stevens Institute of Technology in Hoboken, New Jersey. Dr. Koen's background includes over 19 years of experience in companies such as Becton Dickinson and AT\&T Bell Laboratories. Dr. Koen is supporting the Institute by doing this survey in order to better align curriculum initiatives with the needs of the employers. 